\title{
Spirituality and religiosity in the context of drug abuse
}

\author{
Espiritualidade e religiosidade no contexto do uso abusivo de drogas
}

Ana Lívia Castelo Branco de Oliveira ${ }^{1}$, Carla Danielle Araújo Feitosa ${ }^{1}$, Ariane Gomes dos Santos ${ }^{1}$, Larissa Alves de Araújo Lima ${ }^{1}$, Márcia Astrês Fernandes ${ }^{1}$, Claudete Ferreira de Souza Monteiro ${ }^{1}$

Objective: to investigate the influence of spirituality/religiosity in the context of drug abuse. Methods: this is an integrative review, conducted on the databases Web of Science, Latin American and Caribbean Literature in Health Sciences and SCOPUS. The following descriptors were used in the Portuguese and English languages: drug users, spirituality, religion, drug abuse treatment centers and treatment outcome. Results: eight articles were analyzed, among which there was a prevalence of publications of the year 2015 and of quantitative studies. The studies approached mainly the prevention of drug abuse, the change of the user's behavior and the religious/ spiritual confrontation. Conclusion: spirituality/religiosity seems to be a positive factor for drug users facing treatment, as well as in the protection against the abusive use of these psychoactive substances.

Descriptors: Spirituality; Religion; Drug Users.

Objetivo: investigar a influência da espiritualidade/religiosidade no contexto do uso abusivo de drogas. Métodos: trata-se de uma Revisão Integrativa, realizada a partir das bases de dados Web of Science, Literatura Latino-Americana e do Caribe em Ciências da Saúde e SCOPUS. Utilizaram-se, nos idiomas português e inglês, os seguintes descritores: usuários de drogas, espiritualidade, religião, centros de tratamento de abuso de substâncias e resultado do tratamento. Resultados: foram analisados oito artigos, dos quais houve predomínio de publicações do ano de 2015 e de estudos quantitativos. Os estudos mostraram principalmente a prevenção do uso de drogas, a mudança de comportamento do usuário e o enfrentamento religioso/espiritual. Conclusão: a espiritualidade/religiosidade parece favorecer uma ótica positiva frente ao enfrentamento do tratamento de usuários, bem como na proteção ao uso abusivo dessas substâncias psicoativas.

Descritores: Espiritualidade; Religião; Usuários de Drogas.

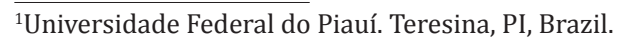




\section{Introduction}

The use of psychoactive substances is an old-aged human practice. In various societies, drugs have been used for religious, cultural and medicinal purposes. However, in the mid-twentieth century, consumption has become a worldwide concern due to social damage, high frequency of consumption and its illegal trade $^{(1)}$.

World estimates indicate that approximately 230 million people aged from 15 to 64 years use illicit drugs every year. Of these, 27 million, corresponding to $0.6 \%$ of the world population, have problems arising from this practice ${ }^{(2)}$. In this sense, reflection on the problem of drug abuse in the context of its users is crucial, since drug abuse has wide repercussions for the individual, his/her family, society and public health.

In Brazil, the use of alcohol and other drugs has been widely debated due to the growing concern about the consumption habits of these licit and illicit drugs, as well as to their social and economic impact and their implications on the health of the population ${ }^{(3)}$.

Despite these high rates of use of psychoactive substances, there still have been deficiencies in the care of drug users due to the difficulty in identifying protective aspects and risk factors that permeate the dysfunctional use of drugs ${ }^{(4)}$.

For this purpose, the different dimensions that make up the human being must be considered. Among them, there are spirituality and religiosity, which are considered important allies in people's lives and partly responsible for helping to prevent self-destructive behaviors related to substance abuse ${ }^{(5)}$.

Spirituality and religiosity are distinct constructs, since spirituality encompasses the existential domain and the essence of what being human is, providing meaning to life through feelings of hope and faith, capable of promoting the well-being of individuals. Religiosity, in turn, is the expression of spirituality characterized by the adoption of values, beliefs and ritual practices ${ }^{(6)}$.
In this perspective, religiosity and spirituality are issues of great relevance, since they influence mental health and have been neglected by psychiatry in their studies and treatment and prevention programs. In studies conducted with the general population, these variables are only explored as a sociodemographic information, which makes it difficult to understand the way they influence individuals, especially in the context of abusive use of alcohol and other drugs ${ }^{(7)}$.

In the dimension of the drug problem, both religiosity and spirituality have been considered as protective factors for the consumption of alcohol and other drugs in preventive and treatment scope, being associated with better life skills and physical and mental well-being of the human being ${ }^{(8)}$.

In this sense, observing the importance of spirituality/religiosity in personal life, social relations, attitudes and health-disease process, including the use of psychoactive substances, the present study aimed to investigate the influence of spirituality/religiosity in the context of drug abuse.

\section{Methods}

This is an integrative review, conducted according to the method that proposes six steps: 1) identification of the theme and selection of the hypothesis or research question; 2) establishment of criteria for inclusion and exclusion of studies; 3 ) definition of the information to be extracted from the selected studies; 4) evaluation of the studies included in the integrative review; 5) interpretation of the results and 6) presentation of the review with the knowledge synthesis ${ }^{(9)}$.

The central question was formulated by means of the PICo technique, where P refers to the population/problem; I refers to interventions; Co refers to context. The following structure was therefore considered: P - drug users; I - spirituality/religiosity; Co - drug abuse, substance abuse treatment centers and treatment outcome. Thus, the following guiding question was elaborated: "what is the influence of spiritu- 
ality/religiosity in the context of abusive drug use?".

The descriptors used for searching in the Web of Science and SCOPUS (provided by the Medical Subject Headings - MeSH) were: drug users, spirituality, religion, substance abuse treatment centers and treatment outcome. Descriptors in the Latin American and Caribbean Literature in Health Sciences (provided by the Descritores de Ciências em Saúde - DeCS) were: usuários de drogas, espiritualidade, religião, centros de tratamento de abuso de substâncias and resultado do tratamento.

The search was carried out in November, 2016 and included publications indexed in the following electronic databases: Web of Science, Latin American and Caribbean Literature in Health Sciences (LILACS) and SCOPUS.

Considering that the databases have different characteristics and peculiarities, the search was carried out using different strategies, by applying the respective filters. In the databases Web of Science and SCOPUS, in the first strategy, the following descriptors were combined: drug users, spirituality and religion. The first descriptor was combined with the second one using the Boolean operator "AND" and the second descriptor was combined with the third one using "OR". In the second strategy, the following descriptors were combined: spirituality, substance abuse treatment centers and treatment outcome. Between the first and second descriptors, the "AND" was used and between the second and third, the Boolean operator "OR" was used. Soon after, in order to unite them, the Boolean operator "AND" was used in the Web of Science and in the SCOPUS, the Boolean operator "AND NOT" was used.

In the database Latin American and Caribbean Literature in Health Sciences (LILACS), the descriptors espiritualidade, centros de tratamento de abuso de substâncias and resultado do tratamento were used in the first search strategy. The first descriptor was combined with the second one using the Boolean operator "AND" and the second descriptor was combined with the third one using the "OR". In the second strategy, the descriptors employed were: usuários de drogas, espiritualidade and religião. Between the first and second descriptors, the "AND" was used and between the second and third, the Boolean operator "OR" was used. Finally, the two strategies were combined using the Boolean operator "AND".

In the database Web of Science, when the first strategy was applied, the quantity of articles was 14,966 . In the second strategy, 172,173 articles were obtained. By combining the two strategies, 125 articles were found, of which, after full reading, three articles remained for qualitative analysis. In SCOPUS, the first strategy used resulted in 323 articles. In the second strategy, the number was 658 articles and, when the strategies were combined, 105 articles were obtained. After full reading, four articles remained. In LILACS, in the first strategy, 210 articles were found; in the second strategy, 236 articles were obtained. By combining the strategies, 12 articles were found and, after full reading, only one article remained. The final sample consisted, therefore, of eight studies.

The selected studies met the inclusion criteria: articles published between the years 2011 and 2016, in English, Spanish and Portuguese languages, that answered the research question. In addition, review articles, case studies, experience reports, book chapters, editorials, theses and dissertations composed the exclusion criteria.

The selection of articles was done through the evaluation of titles, followed by the reading of the summaries and then evaluation of the studies in their entirety. Data of the studies were extracted by means of a data collection instrument elaborated by the authors. They were then synthesized in the form of a table, containing: author, year, country, objectives, methodological approach and main results for the purpose of providing a comparative analysis.

In order to minimize study bias due to errors in the collection and interpretation of the results, two researchers carried out the reading of each article and the filling of the collection instrument, independently. Subsequently, the completion of the instruments was 
compared; in cases of disagreements between them, the authors discussed and reached a consensus.

The analysis of the results was carried out in a descriptive way, proceeding to the categorization of the data extracted from the selected studies, from the identification of variables of interest and key concepts.

\section{Results}

A total of 242 studies were identified, of which 125 were indexed in Web of Science, 105 in SCOPUS and 12 in LILACS. Of these, 12 were excluded due to duplicity. Then, titles and abstracts of 230 articles were read. After this preliminary assessment, 10 articles were read in full for eligibility assessment. Finally, the sample of this review consisted of eight articles.
As shown in Figure 1, regarding the methodological approach, there was prevalence of quantitative studies, with 5 productions, that is, $62.5 \%$ of the sample. Regarding the country of research, 4 (50.0\%) studies were conducted in the United States, followed by $2(25.0 \%)$ in Brazil, 1 (12.5\%) in Jordan and 1 (12, $5 \%)$ in Malaysia.

Studies converged to present objectives aimed at knowing the aspect spirituality/religiosity as a protective factor against the abusive use of substances or as a collaborator in the treatment process. Thus, prevention of drug use, change in user's behavior and religious/spiritual coping were considered. Concepts developed by the collected studies are discussed below.

\begin{tabular}{|c|c|c|c|}
\hline $\begin{array}{l}\text { Author, Year, } \\
\text { Country }\end{array}$ & Objectives & $\begin{array}{l}\text { Methodological } \\
\text { Approach }\end{array}$ & Main results \\
\hline $\begin{array}{l}\text { Miller; Saunders, } \\
2011 \text { (United } \\
\text { States) }{ }^{(10)}\end{array}$ & $\begin{array}{l}\text { Assessing spiritual and religious functioning, } \\
\text { alcohol-related problems, and psychiatric } \\
\text { symptoms. }\end{array}$ & $\begin{array}{l}\text { Quantitative } \\
\text { Approach }\end{array}$ & $\begin{array}{l}\text { Spiritual and religious practices were } \\
\text { predictive of changes in alcohol-related } \\
\text { problems. }\end{array}$ \\
\hline $\begin{array}{l}\text { Rocha; } \\
\text { Guimarães; } \\
\text { Cunha, } 2012 \\
\text { (Brazil) }^{(11)}\end{array}$ & $\begin{array}{l}\text { Understanding the recovery process of drug abuse } \\
\text { experienced by believers in Assembly of God } \\
\text { Pentecostal churches. }\end{array}$ & $\begin{array}{l}\text { Qualitative } \\
\text { approach }\end{array}$ & $\begin{array}{l}\text { Users' motivations for seeking the church } \\
\text { were demonstrated, indicating that the } \\
\text { recovery process involves totalizing and } \\
\text { individual elements. }\end{array}$ \\
\hline $\begin{array}{l}\text { Brown; Tonigan; } \\
\text { Pavlik; Kosten; } \\
\text { Volk, } 2013 \\
\text { (United States) }^{(12)}\end{array}$ & $\begin{array}{l}\text { Describing substance use among the population, } \\
\text { treatment history, self-efficacy, spirituality and } \\
\text { demographics; and comparing reported spirituality. }\end{array}$ & $\begin{array}{l}\text { Quantitative } \\
\text { Approach }\end{array}$ & $\begin{array}{l}\text { Interventions resulting in modest changes } \\
\text { in spiritual beliefs may lead to greater } \\
\text { self-efficacy and contribute to a successful } \\
\text { recovery. }\end{array}$ \\
\hline $\begin{array}{l}\text { Palamar; } \\
\text { Kiang; Halkitis, } \\
\text { 2014(United } \\
{\text { States })^{(13)}}^{\text {(13) }}\end{array}$ & $\begin{array}{l}\text { Examining how different religious aspects as well } \\
\text { as the level of exposure to users predict the use of } \\
\text { emerging drugs. }\end{array}$ & $\begin{array}{l}\text { Quantitative } \\
\text { Approach }\end{array}$ & $\begin{array}{l}\text { The level of religious assiduity was a } \\
\text { protective factor against marijuana and the } \\
\text { use of cocaine. }\end{array}$ \\
\hline $\begin{array}{l}\text { Gonçalves; } \\
\text { Santos; Pillon, } \\
2014 \\
\text { (Brazil) }^{(14)}\end{array}$ & $\begin{array}{l}\text { Assessing aspects of spirituality and religiosity in } \\
\text { alcohol and/or drug users. }\end{array}$ & $\begin{array}{l}\text { Quantitative } \\
\text { Approach }\end{array}$ & $\begin{array}{l}\text { Alcohol users were Catholics }(63.1 \%) \text { and } \\
\text { non-religious }(50.8 \%) \text {, and drug users were } \\
\text { evangelical }(43.1 \%) \text { and practiced a religion } \\
(72.2 \%) \text {. }\end{array}$ \\
\hline $\begin{array}{c}\text { Al-Omari; } \\
\text { Hamed; Tariah, } \\
2015 \text { (Jordan) }^{(15)}\end{array}$ & $\begin{array}{l}\text { Understanding the role of religion in recovery from } \\
\text { alcohol use and substance abuse among Jordanian } \\
\text { adults. }\end{array}$ & $\begin{array}{l}\text { Qualitative } \\
\text { approach }\end{array}$ & $\begin{array}{l}\text { Religion is evidenced as a peace of mind, as } \\
\text { a new beginning, as protection and as an } \\
\text { incentive and increase of motivation. }\end{array}$ \\
\hline $\begin{array}{l}\text { Ghani et al, } 2015 \\
\text { (Malaysia) }^{(16)}\end{array}$ & $\begin{array}{l}\text { Exploring patients' perspectives and satisfaction } \\
\text { with treatment and services at the new Center for } \\
\text { Healing and Care. }\end{array}$ & $\begin{array}{l}\text { Qualitative } \\
\text { approach }\end{array}$ & $\begin{array}{l}\text { Patients identified religious instruction as an } \\
\text { important factor contributing to success of } \\
\text { the treatment. }\end{array}$ \\
\hline $\begin{array}{l}\text { Giordano et al, } \\
2015 \text { (United }^{(17)}\end{array}$ & $\begin{array}{l}\text { Investigating religious coping and spirituality } \\
\text { regarding the dangerous consumption of alcohol, } \\
\text { use of marijuana and use of psychostimulant drugs. }\end{array}$ & $\begin{array}{l}\text { Quantitative } \\
\text { Approach }\end{array}$ & $\begin{array}{l}\text { Positive religious coping and spirituality } \\
\text { protect against the dangerous use of alcohol } \\
\text { and marijuana. }\end{array}$ \\
\hline
\end{tabular}

Figure 1 - Distribution of articles selected by author, year, country, objectives, methodological approach and main results 


\section{Discussion}

Studies related to the influence of spirituality/ religiosity in the context of drug abuse are still scarce in the Brazilian and foreign literature, and this was a limitation of the present integrative review. Therefore, this research contributes to elucidate this issue and to encourage more in-depth publications on the subject.

In this sense, this study brings contributions in the scientific and practical field since health professionals, especially nurses, need to be aware of the need to see the drug user as a holistic being, who also experiences their beliefs and, from these, finds well-being, in order to contribute to the success of their treatment.

The analyzed publications evidenced that spirituality/religiosity is present in the daily life of drug users in their most diverse levels of relationship with substance (abusive use, chemical dependence, in institutional or non-institutional treatment), and that there is an important link between users undergoing treatment who use spirituality/religiosity as an alternative resource.

Studies showed that the relationship between spirituality, religiosity and misuse of alcohol and other drugs has been debated for many years, but the number of published studies shows that its influence is still relatively little analyzed when compared to investigations that discuss these factors only as mere sociodemographic data ${ }^{(14-15)}$.

As observed in the studies described in the present review, the use of drugs, mainly alcohol, has been described in the literature as an aspect influenced by the professed religion and by the religious practice of the individual, acting as a protective factor for the population towards the use of substances ${ }^{(18)}$.

Spirituality also offers a source of personal strength for the individual, a more optimistic orientation of life and greater resilience to stress and less anxiety. Thus, approaches that consider this practice are effective for reducing relapses ${ }^{(14)}$. One example was the changes in the behavior of hazardous alcohol consumption reported by university students, which was influenced by spirituality and religious coping. Thus, the older the individuals, the greater the spirituality, as more bonds with their personal beliefs began to be established, and therefore decisions such as those related to drug abuse ${ }^{(17)}$.

Consistent with the aforementioned studies, the importance of adding rehabilitation and rehabilitation methodologies that are related to other dimensions of life is emphasized. In this way, the importance of a holistic approach to the problem of chemical dependence is emphasized. This was proved by the satisfaction of drug users who opted for treatment in those centers that offered, besides the religious element, other treatment services ${ }^{(16)}$.

In this perspective, in analyzing the literature on the influence of spirituality and religiosity in the context of drug abuse, interviewees of a survey conducted in Jordan reported that religion is a basic element in the recovery process, collaborating in reducing addiction and producing a new beginning. In this way, individuals who recover will learn new skills and behaviors to deal with life stressors and will keep away from substance abuse again. This behavioral modification is related to the fact that these participants live in a country of Muslim religion, in which the consumption of alcohol and other substances is prohibited $^{(15)}$.

However, regardless of the country, spirituality brings balance and stability to life, and thus facilitates the maintenance of abstinence, which has a positive impact on interpersonal/family relationships ${ }^{(14)}$.

When it comes to recovery from addiction, other factors and elements must be linked to the spiritual dimension, such as family, self-development, and even a life-changing attempt after traumatic experiences of drug trafficking. In this perspective, scholars find that the factors that generate users' adherence to religious practice can be the possibility of associating with a group respected by these users, the proxi- 
mity of the family to the church and existential crisis to the detriment of psychic trauma generated by the drug ${ }^{(11)}$. According to the results of this integrative review, such aspects contribute positively to distancing people from drug abuse, as well as to successful treatment.

A study developed in the United States evidenced that although spirituality and religiosity are individual, they are mechanisms of behavior change, contributing to a successful recovery from addiction. And religious users believe in a greater power, responsible for their behavioral renewal ${ }^{(12)}$.

Spirituality and religiosity are potentially responsible for healthy behavior and well-being. In a study carried out with patients from centers for outpatient treatment of chemical dependents, regarding the spirituality aspect, there was a change in the behavior of alcoholic individuals and in their mental health ${ }^{(10)}$.

For users assisted in a Center for Psychosocial Care on Alcohol and Drugs in the interior of São Paulo state, religion positively influences treatment, assuming meaning and complementary support role. It allows, in the perception of drug users, a contribution of knowledge that helps them to understand the damages caused by the drug and to assume they are addicted $^{(8)}$.

Considering the common contributions, religiosity and spirituality are protective elements regarding the use of drugs, and they bring positive interferences in the process of treatment and psychosocial rehabilitation of chemical dependence. In this way, there has been increasing demand of drug users for centers of comprehensive treatment whose intervention resource is of a religious/spiritual nature and which prioritizes the distance from the social life and, therefore, conditions that favor drug-related risk behaviors ${ }^{(14)}$.

Regarding the aforementioned protective factor, a research conducted in the United States was also observed that high levels of religious participation may protect individuals from using illicit drugs; however, this protective aspect should not be generalized to all variations of psychoactive substances ${ }^{(13)}$.

In this sense, a study pointed out that religious instruction as intervention in drug users has reduced the symptoms of abstinence and drug craving. However, even though they received all the psychic support for confrontation and treatment progress, users expressed hesitation and uncertainty about the futu$\mathrm{re}^{(16)}$.

The relationship between the believer and the church is a dialectic relationship that favors the discovery of potentialities of the individual, allowing greater social support and therefore self-esteem, which interferes with the adherence/maintenance of risk behaviors in relation to drugs. Meanwhile, churches aim to transform society and the individual in transformation through its religious doctrines, disregarding the broad social and structural context surrounding chemical dependence ${ }^{(11)}$.

In this sense, in the light of the investigated productions, religious and spiritual beliefs help in the behavioral change of the users, as well as help in the abandonment and reduce the use of drugs, acting as protective factors. These results corroborate the fact that knowing the religiosity, spirituality and personal beliefs of chemical dependents, the coping mechanisms related to treatment, reception, listening, as well as the integration of facets of spirituality, religion and personal beliefs can be integrated with user care practices $^{(19)}$.

\section{Conclusion}

The reading of studies that dealt with the theme of spirituality and religiosity in the context of drug use enabled to observe that these aspects seem to favor a positive view regarding the coping of the treatment by users, as well as in the protection of the abusive use of these psychoactive substances. In this sense, these factors constitute promising resources for health maintenance, prevention and rehabilitation. 


\section{Collaborations}

Oliveira ALCB, Feitosa CDA, Santos AG and Lima LAA contributed to project design, search and analysis, article writing and final evaluation of the version to be published. Fernandes MA and Monteiro CFS contributed to project design, article writing and final evaluation of the version to be published.

\section{References}

1. Marangoni SR, Oliveira MLF. Triggering factors for drug abuse in women. Texto Contexto Enferm. 2013; 22(3):662-70.

2. Capistrano FC, Ferreira ACZ, Silva TL, Kalinke LP, Maftum MA. Perfil sociodemográfico e clínico de dependentes químicos em tratamento: análise de prontuários. Esc Anna Nery. 2013; 17(2):234-41.

3. Vale JS, Uesugui HM, Pereira RA. Perfil do consumo de álcool, tabaco e maconha entre graduandos em enfermagem da Faculdade de Educação e Meio Ambiente - Faema. Rev Cient Faculd Educ Meio Ambient. 2014; 5(2):156-72.

4. Kassada DS, Marcon SS, Pagliarini MA, Rossi RM. Prevalence of drug abuse among pregnant women. Acta Paul Enferm [Internet]. 2013 [cited 2016 nov 20]; 26(5):467-71. Available from: http://www. scielo.br/pdf/ape/v26n5/en_a10v26n5.pdf

5. Backes DS, Backes MS, Medeiros HMF, Siqueira DF, Pereira SB, Dalcin CB, et al. Spirituality workshops: alternative care for the comprehensive treatment of drug addicts. Rev Esc Enferm USP [Internet]. 2012 [cited 2016 nov 20]; 46(5):1254-9. Available from: http://www.scielo.br/pdf/reeusp/v46n5/ en_30.pdf

6. Nascimento LC, Santos TFM, Oliveira FCS, Pan R, Flória-Santos M, Rocha SMM. Espiritualidade e religiosidade na perspectiva de enfermeiros. Texto Contexto Enferm. 2013; 22(1):52-60.

7. Pillon SC, Santos MA, Gonçalves AMS, Araújo KM, Funai A. Fatores de risco, níveis de espiritualidade e uso de álcool em estudantes de dois cursos de enfermagem. Rev Eletr Saúde Mental Álcool Drog [Internet]. 2010 [cited 2016 nov 20]; 6(spe):493513. Disponível em: http://pepsic.bvsalud.org/ pdf/smad/v6nspe/08.pdf
8. Zerbetto SR, Gonçalves AMS, Santile N, Galera SAF, Acorinte AC, Giovannetti G. Religiosity and spirituality: mechanisms of positive influence on the life and treatment of alcoholics. Esc Anna Nery [Internet]. 2017 [cited 2017 Jan 13]; 21(1):e20170005. Available from: http://www. scielo.br/pdf/ean/v21n1/en_1414-8145-ean-2101-e20170005.pdf

9. Mendes KDS, Silveira RCCP, Galvão CM. Revisão integrativa: método de pesquisa para a incorporação de evidências na saúde e na enfermagem. Texto Contexto Enferm. 2008; 17(4):758-64.

10. Miller ML, Saunders SM. A Naturalistic study of the associations between changes in alcohol problems, spiritual functioning, and psychiatric symptoms. Psychol Addict Behav. 2011 [cited 2016 nov 20]; 25(3):455-61. Available from: https://www.ncbi.nlm.nih.gov/pmc/articles / PMC3132244.

11. Rocha MA, Guimarães MBL, Cunha MB. 0 processo de recuperação do uso indevido de drogas em igrejas pentecostais Assembleia de Deus. Interface [Internet]. 2012 [citado 24 nov 16]; 16(40):177-90.Disponível em: http://www.scielo. br/scielo.php?script=sci_arttext $\&$ pid $=$ S141432832012000100014\&lng=en

12. Brown AE, Tonigan JS, Pavlik VN, Kosten TR, Volk RJ. Spirituality and confidence to resist substance use among celebrate recovery participants. J Relig Health [Internet]. 2013 [cited 2016 nov 21]; 52(1):107-13. Available from: https://www.ncbi. nlm.nih.gov/pubmed/21246280

13. Palamar JJ, Kiang MV, Halkitis PN. Religiosity and exposure to users in explaining illicit drug use among emerging adults. J Relig Health [Internet]. 2014 [cited 2016 nov 23]; 53(3):658-74. Avaiable from:https://www.ncbi.nlm.nih.gov/labs / articles/23114835/

14. Goncalves MAS, Santos MA, Pillon SC. Uso de álcool e/ou drogas: avaliação dos aspectos da espiritualidade e religiosos. Rev Eletr Saúde Mental Álcool Drog [Internet]. 2014 [citado 24 nov 16]; 10(2):61-9. Disponível em: http://www.revistas. usp.br/smad/article/view/98719/97281 
15. Al-Omari H, Hamed R, Abu Tariah H. The Role of Religion in the Recovery from Alcohol and Substance Abuse Among Jordanian Adults. J Relig Health [Internet]. 2015 [cited 2016 nov 21]; 54(4):1268-77. Avaiable from: https://www.ncbi. nlm.nih.gov/pubmed/24788615

16. Ghani MA, Brown SE, Khan F, Wickersham JA, Lim SH, Dhaliwal SK, Kamarulzaman A, Altice FL. An exploratory qualitative assessment of selfreported treatment outcomes and satisfaction among patients accessing an innovative voluntary drug treatment centre in Malaysia. Int J Drug Policy [Internet]. 2015 [cited 2016 nov 25]; 26(2):175-82. Available from: https://www.ncbi. nlm.nih.gov/pubmed/25577322.

17. Giordano AL, ProsekEA, Daly CM, Holm JM, Ramsey ZB, Abernathy MR, et al. Exploring the relationship between religious coping and spirituality among three types of collegiate substance abuse. J Couns Dev. 2015 [cited 2016 nov 28]; 93:1. Available from: http://onlinelibrary.wiley.com/ doi/10.1002/j.1556-6676.2015.00182.x/abstract
18. Gonçalves AMS, Santos MA, Chaves ECL, Pillon SC. Transcultural adaptation and validation of the Brazilian version of Treatment Spirituality/ Religiosity Scale. Rev Bras Enferm. 2016; 69(2):235-41.

19. Bettarello VC, Silva LMA, Molina NPFM, Silveira T, Rodrigues LR. Quality of life, spirituality, religion and personal beliefs of chemical dependents in treatment. Rev Eletr Enf [Internet]. 2016 [cited 2016 nov 28];18:e1194. Available from: http:// dx.doi.org/10.5216/ree.v18.41677 